\title{
Hyperglycemia- and hyperinsulinemia-induced alteration of adiponectin receptor expression and adiponectin effects in L6 myoblasts
}

\author{
X Fang, R Palanivel, X Zhou, Y Liu, A Xu' ${ }^{1}, Y$ Wang ${ }^{2}$ and G Sweeney \\ Department of Biology, York University, Toronto, M3J 1P3, Canada \\ ${ }^{1}$ Department of Medicine and ${ }^{2}$ Genome Research Center, Faculty of Medicine, University of Hong Kong, 21 Sasson Rd., Pokfulam, Hong Kong, China \\ (Requests for offprints should be addressed to G Sweeney; Email: gsweeney@yorku.ca)
}

\begin{abstract}
Adiponectin has been shown to regulate glucose and fatty acid uptake and metabolism in skeletal muscle. Here we investigated the role of the recently cloned adiponectin receptor (AdipoR) isoforms in mediating effects of both globular $(\mathrm{gAd})$ and full-length $(\mathrm{fAd})$ adiponectin, and their regulation by hyperglycemia $(25 \mathrm{mM}, 20 \mathrm{~h})$ and hyperinsulinemia (100 nM, 20 h). We used L6 rat skeletal muscle cells, which were found to express both AdipoR1 and AdipoR2 mRNA in a ratio of over 6:1 respectively. Hyperglycemia and hyperinsulinemia both decreased AdipoR1 receptor expression by approximately $50 \%$, while the latter induced an increase of approximately threefold in AdipoR2 expression. The ability of gAd to increase GLUT4 myc translocation, glucose uptake, fatty acid uptake and oxidation, as well as AMP-activated protein kinase (AMPK) and acetyl-CoA carboxylase (ACC) phosphorylation, was decreased by both hyperglycemia and hyperinsulinemia. Interestingly, hyperinsulinemia induced the ability of fAd to elicit fatty acid uptake and enhanced fatty acid oxidation in response to fAd. In summary, our results suggest that both hyperglycemia and hyperinsulinemia cause gAd resistance in rat skeletal muscle cells. However, hyperinsulinemia induces a switch toward increased fAd sensitivity in these cells.
\end{abstract}

Journal of Molecular Endocrinology (2005) 35, 465-476

\section{Introduction}

The association between obesity and diabetes has prompted great interest in the metabolic effects of adipokines (Kershaw \& Flier 2004). In this study, we focus on adiponectin (Acrp30), a 247-amino-acid peptide with sequence similarity to complement factor Clq and structural homology to tumor necrosis factor (TNF)- $\alpha$ (Scherer et al. 1995). Adiponectin mRNA expression and circulating levels are reduced in obese (Statnick et al. 2000, Halleux et al. 2001, Yang et al. 2001, Fisher et al. 2002, Milan et al. 2002, Altomonte et al. 2003) and lipoatrophic (Yamauchi et al. 2001, Vigouroux et al. 2003) humans or rodent models. Adiponectin has been shown to have antidiabetic, anti-inflammatory and antiatherosclerotic effects (Diez \& Iglesias 2003, Haluzik et al. 2004). Indeed, adiponectin can both improve insulin sensitivity and mediate direct effects on glucose and fatty acid metabolism in skeletal muscle, adipocytes and liver (for reviews, see Berg et al. 2002, Tsao et al. 2002, Goldfine \& Kahn 2003, Haluzik et al. 2004).

Adiponectin contains 22 collagen repeats in the N-terminal domain and a Clq-like C-terminal globular domain (Scherer et al. 1995). Regulation of physiologic responses to adiponectin is complicated and occurs at many levels, including formation of oligomers, enzymatic cleavage and availability of its receptor isoforms. Full-length adiponectin (fAd), which is thought to mediate primarily effects in liver, may be cleaved (Waki et al. 2005) to liberate a fragment containing the globular domain (gAd), which can also directly mediate metabolic effects, particularly in skeletal muscle (Fruebis et al. 2001, Yamauchi et al. 2003, Ceddia et al. 2005). Adiponectin monomers can form trimeric or higher order complexes that may each have different potency for, and end-point responses in, different tissues (Tsao et al. 2002a, 2003, Waki et al. 2003). Although some debate exists, circulating fAd has been found in monomeric, trimeric, hexameric and higher order forms, whereas gAd exists as both a monomer and trimer (Fruebis et al. 2001, Yamauchi et al. 2002, 2003, Pajvani et al. 2003, 2004, Shklyaev et al. 2003, Shoji et al. 2004, Wang et al. 2004). While the high-, medium- and low-molecular-weight complexes of fAd are the primary circulating forms of adiponectin, recent evidence for localized cleavage to produce gAd makes it imperative to study the effect of gAd, particularly in muscle. Two adiponectin receptor (AdipoR) isoforms were recently discovered (Yamauchi et al. 2003); AdipoR 1 has a high affinity for gAd and low affinity for fAd, whereas AdipoR2 exhibits intermediate 
binding affinity for both gAd and fAd. A potential pathophysiologic role for alterations in Adipo $\mathrm{R}$ is supported by a positive correlation between receptor expression and insulin resistance (Civitarese et al. 2004) and plasma insulin levels (Inukai et al. 2004, Tsuchida et al. 2004), lower AdipoR1 and AdipoR2 expression in patients with a family history of diabetes (Civitarese $e t$ al. 2004), and increased skeletal muscle AdipoRl expression in streptozotocin (STZ)-diabetic mice (Inukai et al. 2004, Tsuchida et al. 2004). Here we characterized the effect of chronic insulin and glucose treatment on AdipoR expression and investigated whether the observed changes correlated with alterations in the functional effects of gAd and fAd on glucose and fatty acid uptake and metabolism in rat skeletal muscle cells.

\section{Materials and methods}

\section{Materials}

$\left[1-{ }^{14} \mathrm{C}\right]$ Oleic acid and 2-deoxy-D- $\left[{ }^{3} \mathrm{H}\right]$ glucose were purchased from Amersham (Quebec, Canada). BODIPY-conjugated palmitate was from Molecular Probes (Eugene, OR, USA). Insulin (Humulin) was purchased from Eli Lilly (Toronto, Canada). Recombinant human globular adiponectin (gAd) was purchased from Peprotech (Ottawa, Canada). Antifade solution was from Dako (Kyoto, Japan). TRIzol reagent and Platinum SYBR Green qPCR SuperMix UDG Kit were from Invitrogen Life Technologies (Burlington, Canada). Anti-myc monoclonal antibody, AMP-activated protein kinase (AMPK)- $\alpha 1$ and AMPK- $\alpha 2$ were from Santa Cruz (Santa Cruz, CA, USA). All other antibodies are from Cell Signalling (Beverly, MA, USA). PVDF membrane and HRP-linked secondary antibodies were from BioRad (Burlington, Canada). o-Phenylenediamine dihydrochloride (OPD) and all other chemicals and primers were from Sigma. All cell culture components were from Wisent (Quebec, Canada).

\section{Cell culture}

Rat L6 skeletal myoblasts were grown in $\alpha$-minimum essential medium (aMEM) containing 10\% (v/v)) fetal bovine serum (FBS) (growth medium) under $5 \% \mathrm{CO}_{2}$ at $37^{\circ} \mathrm{C}$. We used wild-type L6 cells or cells stably transfected to overexpress stably GLUT4 harboring a myc epitope on the first exofacial loop of the transporter (L6 GLUT4 myc cells, a kind gift from Dr Amira Klip, Hospital for Sick Children, Toronto). This facilitated accurate quantitative analysis of GLUT4 translocation in intact cells. For experimental procedures, cells were cultured in aMEM (5 mM glucose) containing $2 \%(\mathrm{v} / \mathrm{v})$ FBS plus $1 \%$ antibiotic/antimycotic, which was supplemented with or without final concentrations of $25 \mathrm{mM}$ glucose or $100 \mathrm{nM}$ insulin, as indicated in figure legends.

\section{Analysis of adiponectin receptors expression by real-time quantitative PCR}

cDNAs were synthesized by reverse transcription with $1 \mu \mathrm{g}$ total RNA. Primers for real-time quantitative PGR were based on sequences of adiponectin receptors in L6 myoblasts (see Results). Primer sequences and their respective PCR fragment length were as follows:

AdipoR1 (158 bp): forward 5'-GGTGGCGTTTA TGCTGCTCG-3, reverse 5'-TCTAGGCGGTAAGG GAATTC-3'

- AdioR2 (415 bp): forward 5'-CGCTCTGCAAG AGAAAGTGG-3', reverse 5'-TAGCGAGCGTATCT GCGCTA-3'

- $\beta$-actin (133 bp): forward 5'-CTGTGCGCATCTA TGAGGGT-3', reverse 5'-CTCTCAGCTTGGTGGT GAA-3'

AdipoR1 and AdipoR2 RNA levels in L6 myoblasts were determined by using platinum SYBR Green qPCR SuperMix UDG Kit. L6 myoblasts were incubated with insulin $(100 \mathrm{nM})$ or glucose $(25 \mathrm{mM})$ for the times indicated, and then RNA was extracted and reverse transcribed to cDNA. Cycling conditions consisted of an initial denaturation step of $95^{\circ} \mathrm{C}$ for 3 min followed by 40 cycles of $95^{\circ} \mathrm{C}$ for $30 \mathrm{~s} / 60{ }^{\circ} \mathrm{C}$ (AdipoRl and AdipoR2) or $65^{\circ} \mathrm{C}$ ( $\beta$-actin) for $30 \mathrm{~s} / 72^{\circ} \mathrm{C}$ for $30 \mathrm{~s}$.

\section{Production of globular and full-length adiponectin}

For this work, we chose to express and purify recombinant gAd by subcloning murine gAd cDNA (a kind gift from Dr Philipp Scherer, Albert Einstein College of Medicine, New York City) into the pTrisEx expression vector (Novagen). Expression of the $\mathrm{N}$-terminal His6-tagged fusion protein was then induced in $E$. coli with IPTG. Recombinant gAd was isolated from the bacterial cell lysate with a nickel column according to the manufacturer's instruction (Sigma). Mass spectrometry analysis confirmed the production and isolation of gAd (data not shown). We have also used commercially available human gAd (Peprotech) to validate our results and, despite batch to batch variability, we found similar results with both. It has been suggested that bacterially produced fAd is inactive (Berg et al. 2001, Yamauchi et al. 2001, 2002) and that fAd must be appropriately post-translationally modified before it can inhibit gluconeogenesis, increase fatty acid oxidation, reduce steatosis, increase CPT-1 activity and decrease acetyl-CoA carboxylase (ACG) activity in liver (Wang et al. 2002, Xu et al. 2003). Therefore, here we used full-length post-translationally modified Ad produced in a mammalian expression system, as previously described (Wang et al. 2002, Xu et al. 2003).

\section{Measurement of glucose uptake}

Cells were incubated with insulin $(100 \mathrm{nM})$ or glucose $(25 \mathrm{mM})$ for $20 \mathrm{~h}$, and subsequently serum-starved in the 
continued presence of insulin or glucose for the final $4 \mathrm{~h}$ in 24-well plates prior to further treatment. Cells were washed twice with PBS and treated with gAd $(1 \mu \mathrm{g} / \mathrm{ml}$, $2 \mathrm{~h})$ or fAd $(5 \mu \mathrm{g} / \mathrm{ml}, 2 \mathrm{~h})$. After treatments, glucose uptake was determined as previously described (Ceddia et al. 2005). Briefly, cells were incubated in transport solution (140 mM NaCl, $20 \mathrm{mM}$ HEPES-Na, $2.5 \mathrm{mM}$ $\mathrm{MgSO}_{4}, 1 \mathrm{mMCaCl}_{2}, 5 \mathrm{mM} \mathrm{KCl}$ and $0.5 \mu \mathrm{Ci} / \mathrm{ml}$ 2-deoxy-D- $\left[{ }^{3} \mathrm{H}\right]$ glucose $\left.(\mathrm{pH} 7 \cdot 4)\right)$ for $5 \mathrm{~min}$ at room temperature. Nonspecific uptake was measured in the presence of cytochalasin $\mathrm{B}(10 \mu \mathrm{M})$. Cells were then lysed with $1 \mathrm{M} \mathrm{KOH}$, and aliquots were transferred to scintillation vials for ${ }^{3} \mathrm{H}$ radioactivity counting.

\section{Determination of GLUT4 translocation}

The overexpression of GLUT4 with an exofacial myc epitope allows accurate quantification of cell-surface GLUT4 content in intact cells. L6-GLUT4 myc cells were pretreated as described above for glucose uptake, and then cell surface GLUT4 content was determined by an antibody-coupled colorimetric assay, as previously described (Ceddia et al. 2005). Cells were first incubated with primary antibody solution (anti-myc monoclonal antibody) for $1 \mathrm{~h}$ at $4{ }^{\circ} \mathrm{C}$, and fixed with $3 \%$ paraformaldehyde for $3 \mathrm{~min}$. The fixative was then neutralized by $10 \mathrm{mM}$ glycine for $10 \mathrm{~min}$ on ice. Cells were then treated with blocking buffer $3 \%$ BSA, $5 \%$ goat serum in PBS) for $30 \mathrm{~min}$ and incubated with secondary antibody solution (HRPconjugated antimouse antibody) for $1 \mathrm{~h}$ at $4{ }^{\circ} \mathrm{C}$. Finally, $1 \mathrm{ml}$ OPD reagent was added in each well for $30 \mathrm{~min}$, the reaction was stopped by adding $3 \mathrm{M}$ $\mathrm{HCl}$, and the absorbance of supernatant was measured at $492 \mathrm{~nm}$.

\section{Measurement of fatty acid oxidation}

Fatty acid oxidation was measured by the production of ${ }^{14} \mathrm{CO}_{2}$ from $\left[1-{ }^{14} \mathrm{C}\right]$ oleate, as previously described (Ceddia et al. 2005). Briefly, cells in $60 \times 15 \mathrm{~mm}$ Petri dishes were incubated with insulin $(100 \mathrm{nM})$ or glucose $(25 \mathrm{mM})$ for $20 \mathrm{~h}$ and subsequently serum-starved for $4 \mathrm{~h}$. After this incubation period, cells were treated with gAd $(1 \mu \mathrm{g} / \mathrm{ml}, 2 \mathrm{~h})$ or fAd $(5 \mu \mathrm{g} / \mathrm{ml}, 2 \mathrm{~h})$ prepared in serum-free medium containing $0 \cdot 3 \mu \mathrm{Ci} / \mathrm{ml}\left[1-{ }^{14} \mathrm{C}\right]$ oleic acid. $\left[1-{ }^{14} \mathrm{C}\right]$ Oleate and cold oleate $(0.5 \mathrm{mM}$ final concentration) were complexed with defatted BSA at a 2.5:1 ratio. Each Petri dish was sealed with parafilm with a piece of Whatman paper taped facing the inside of the petri dish. The Whatman paper was wet with $100 \mu \mathrm{l}$ phenylethylamine/methanol $(1: 1)$ to trap the $\mathrm{CO}_{2}$ produced during the incubation period. After the 2-h incubation, $200 \mu \mathrm{l} \mathrm{H}_{2} \mathrm{SO}_{4}(4 \mathrm{~mol} / \mathrm{l})$ was added to the cells and incubated for $1 \mathrm{~h}$ at $37^{\circ} \mathrm{C}$. Finally, the sealing from each Petri dish was removed, and the pieces of
Whatman paper were carefully transferred to scintillation vials for radioactivity counting.

\section{Measurement of fatty acid uptake}

To determine fatty acid uptake, we used fluorescent palmitate as previously described (Hirsch et al. 1998, Stahl et al. 2002) with slight modifications. Cells were grown on cover slips and incubated with insulin $(100 \mathrm{nM})$ or glucose $(25 \mathrm{mM})$ for $20 \mathrm{~h}$, and subsequently serum-starved for the final $4 \mathrm{~h}$. Culture medium was removed, and cells washed twice with PBS containing $0 \cdot 1 \%$ fatty acid-free albumin. After this incubation period, cells were treated with gAd $(1 \mu \mathrm{g} / \mathrm{ml})$ or fAd $(5 \mu \mathrm{g} / \mathrm{ml})$ for the times indicated in figure legends. BODIPY-conjugated palmitate $(1 \mu \mathrm{M})$ was prepared in serum-free $\alpha \mathrm{MEM}$ and added to cells. After incubation at $37^{\circ} \mathrm{C}$ for $2 \mathrm{~min}$, cells were washed three times and cover slips were fixed on glass slides with antifade solution. Nonspecific uptake was determined by competition with $5 \mathrm{mM}$ palmitate. For confocal microscopy analysis, BODIPY-conjugated fatty acids were excited at $488 \mathrm{~nm}$ with an Olympus 300 multiline argon laser. Fluorescent images were obtained with Fluoview software, and fluorescence intensity was quantitated by ImageJ software.

\section{Western blot analysis}

Cells were cultured in six-well plates and incubated with insulin $(100 \mathrm{nM})$ or glucose $(25 \mathrm{mM})$ for $20 \mathrm{~h}$ where indicated, serum-starved for $4 \mathrm{~h}$, and then stimulated with $\mathrm{gAd}(1 \mu \mathrm{g} / \mathrm{ml}, 5 \mathrm{~min})$ or fAd $(5 \mu \mathrm{g} / \mathrm{ml}, 5 \mathrm{~min})$. Subsequently, as we previously described (Sweeney et al. 2001, Tajmir et al. 2003), cells were lysed in 1 SDS sample buffer $(62.5 \mathrm{mM}$ Tris- $\mathrm{HCl}(\mathrm{pH} 6 \cdot 8), 2 \% \mathrm{w} / \mathrm{v}$ SDS, $10 \%$ glycerol, $50 \mathrm{mM}$ DTT, $0.01 \% \quad \mathrm{w} / \mathrm{v}$ bromophenol blue, and protease and phosphatase inhibitors $\left(1 \mu \mathrm{M} \quad \mathrm{Na}_{3} \mathrm{VO}_{4}, 1 \mu \mathrm{M}\right.$ leupeptin, $1 \mu \mathrm{M}$ pepstatin, $1 \mu \mathrm{M}$ okadaic acid and $1 \mu \mathrm{M}$ PMSF)), passed through a syringe several times and heated $\left(65^{\circ} \mathrm{C}\right)$ for $5 \mathrm{~min}$. Cell lysates were then centrifuged for $5 \mathrm{~min}$ in a benchtop microfuge (16 $294 \boldsymbol{g}$ ), and approximately $30 \mu \mathrm{g}$ protein was resolved by $10 \%$ SDS-PAGE and then immunoblotted onto PVDF membrane. Membranes were blocked with 3\% BSA dissolved in 1 wash buffer solution of $50 \mathrm{mM}$ Tris-base, $150 \mathrm{mM} \mathrm{NaCl}, 1 \%$ Triton-X-100 and 1\% NP-40 for $1 \mathrm{~h}$. Membranes were incubated overnight with primary antibodies at the following dilutions: phospho-AMPK (1:500), AMPK- $\alpha 1$ (1:500), AMPK- $\alpha 2$ (1:500), phospho-ACG (1:1000), ACG $(1: 1000)$ and $\beta$-actin $(1: 1000)$. Membranes were then washed four times in $1 \times$ wash buffer for $15 \mathrm{~min}$ each at room temperature and then incubated with HRP-coupled secondary antibody $(1: 10000)$ for $1 \mathrm{~h}$. Membranes were washed five times in $1 \times$ wash buffer 
Table 1 Expression of AdipoR1 and AdipoR2 isoforms in L6 myoblasts and rat soleus and EDL muscle. We used quantitative real-time PCR, with $\beta$-actin as reference, to show that the L6 myoblasts used in this study expressed over six-fold more AdipoR1 than AdipR2 mRNA. Analysis of glycolytic (EDL) and oxidative (soleus) rat skeletal muscle demonstrated that L6 cells and EDL expressed a similar AdipoR isoform profile (over $6: 1$ ). Almost no AdipoR2 was detectable in soleus, giving rise to a ratio of approximately 4000-fold more AdipoR1. Results represent mean \pm S.E.M. of $n=3$, and in each case the level of AdipoR 1 expression was assigned an arbitrary value of 1 , and AdipoR2 content was expressed relative to this value

\section{Relative expression ratio}

\begin{tabular}{llll} 
& \multicolumn{1}{c}{ AdipoR1 } & & AdipoR2 \\
\cline { 2 - 2 } L6 myoblasts & 1 & & $0.14 \pm 0.02$ \\
Rat EDL & 1 & & $0.16 \pm 0.03$ \\
Rat soleus & 1 & & $\left(2.5 \times 10^{-4}\right)$ \\
\hline
\end{tabular}

for $10 \mathrm{~min}$ each, and proteins were visualized by enhanced chemiluminescence and quantified by the Scion Image program (Scion Corporation, Frederick, MD, USA).

\section{Results}

\section{Analysis of AdipoR1 and AdipoR2 sequence and expression in L6 cells}

When we initiated this work, the human and mouse, but not rat, AdipoR sequences had been published (Yamauchi et al. 2003), and so we began by cloning and sequencing rat AdipoR1 and AdipoR2 from L6 cells. This was done by extracting total RNA and then cDNA synthesis and PCR amplification with primers designed to recognize mouse AdipoR. The resulting PCR fragment was ligated to pDrive cloning vector, and this was followed by colony screening, plasmid detection and sequencing. We found that rat AdipoR 1 comprises a $1128 \mathrm{bp}$ cDNA sequence which shares $94 \%$ and $90 \%$ identity to mouse and human AdipoRl respectively. These cDNAs encoded proteins showing $98 \%$ and $93 \%$ identity to mouse and human AdipoR1 respectively. The $1161 \mathrm{bp}$ AdipoR2 sequence shares 97\% and 90\% identity to mouse and human AdipoR2 respectively, and 99\% and 96\% identity at the amino-acid level. The sequences have been deposited in Genbank with accession nos DQ148391 for AdipoR1 and DQ148392 for AdipoR2. We also used quantitative real-time PCR, with $\beta$-actin as reference, to show that the L6 myoblasts used in this study express both AdipoR1 and AdipoR2 in a ratio of over 6:1 (Table 1). We used rat extensor digitorum longus (EDL) and soleus muscle for comparison and found a very similar AdipoR expression profile in EDL and L6 myoblasts. In soleus, a very low, and barely detectable, AdipoR2 copy number was observed (Table 1).

\section{Alteration in AdipoR1 and AdipoR2 expression induced by hyperglycemia and hyperinsulinemia}

We used quantitative real-time PCR to investigate the effect of glucose $(25 \mathrm{mM}, 20 \mathrm{~h})$ and insulin $(100 \mathrm{nM}$, $20 \mathrm{~h}$ ) on AdipoR1 and AdipoR2 mRNA expression, using $\beta$-actin as reference. Both hyperglycemia and hyperinsulinemia caused a significant reduction in AdipoR1 expression to approximately $50 \%$ of the original level (Fig. 1A). Hyperinsulinemia increased AdipoR2 expression by almost threefold whereas hyperglycemia had no effect on the expression level of AdipoR2 (Fig. 1B).

\section{Hyperglycemia- and hyperinsulinemia-induced changes in glucose uptake and GLUT4myc translocation in response to $\mathrm{gAd}$ and $\mathrm{fAd}$}

We have demonstrated previously that proper hydroxylation and glycosylation of lysine residues in fAd play a critical role in determining activity of this protein (Wang et al. 2002, Xu et al. 2003). Examination of metabolic responses in liver demonstrated that fAd produced in mammalian expression systems, with appropriate hydroxylation and glycosylation, is significantly more biologically active than fAd produced in bacteria (Wang et al. 2002, Xu et al. 2003). Therefore, for this study, we used fAd produced in COS cells, as previously described by us (Wang et al. 2002, Xu et al. 2003). We and others have demonstrated previously that gAd expressed and purified from bacteria exhibits full activity (Ceddia et al. 2005). We tested whether the ability of gAd or fAd to regulate GLUT4 myc translocation and glucose uptake in L6 cells (Ceddia et al. 2005) may be altered by hyperglycemia or hyperinsulinemia. We found that gAd, but not fAd, increases glucose uptake (Fig. 2A). When cells were grown in a high concentration of insulin, the ability of gAd to increase glucose uptake was lost, but fAd now elicited an increase in glucose uptake of $\sim 1 \cdot 4$-fold (Fig. 2B). The ability of gAd to elicit glucose uptake was reduced by hyperglycemia (Fig. 2C). Absolute values for glucose uptake were 16.55 \pm $2.73 \mathrm{pmol} / \mathrm{min}$ per $\mathrm{mg}$ protein (control) and 25.33 \pm 3.49 and $19 \cdot 22 \pm 0.95$ for high insulin and high glucose conditions respectively. An increase in the amount of GLUT4 myc detected at the cell surface of intact cells was observed in response to gAd, but not fAd (Fig. 3A). A smaller increase in GLUT4 myc translocation in response to gAd was observed under both hyperinsulinemic and hyperglycemic conditions, and there was still no effect of fAd (Fig. 3B and C). 

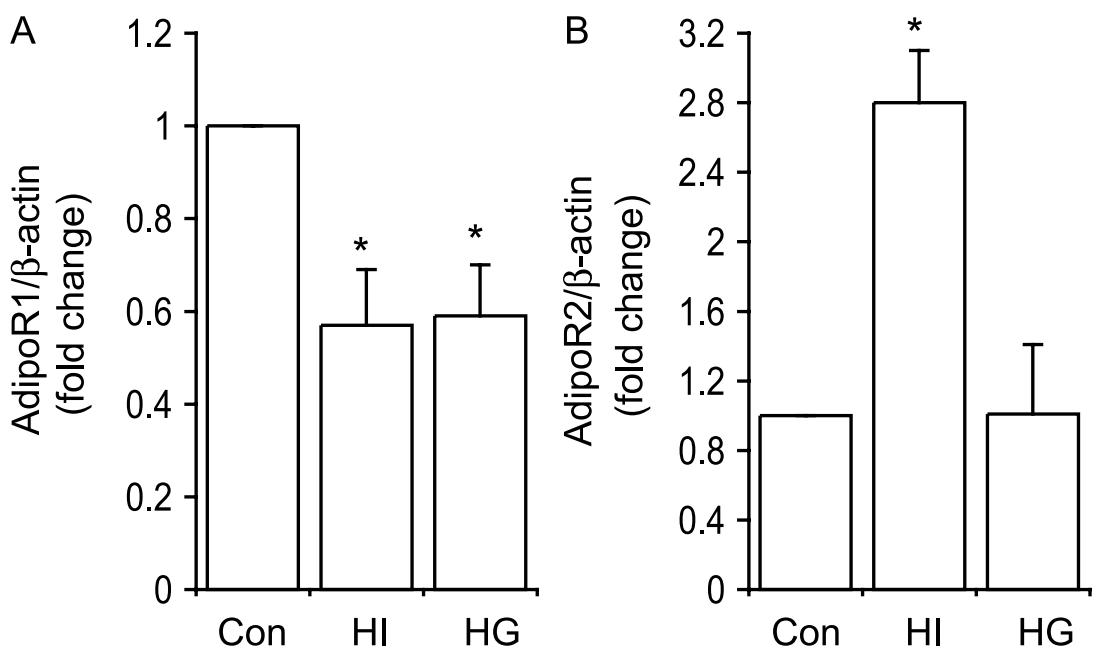

Figure 1 Regulation of AdipoR1 and AdipoR2 expression by hyperinsulinemia and hyperglycemia. The effect of growing cells in the presence of insulin (HI: $100 \mathrm{nM}, 20 \mathrm{~h})$ or glucose (HG: $25 \mathrm{mM}, 20 \mathrm{~h}$ ) on AdipoR mRNA expression with respect to untreated cells (Con) is shown in panels $A$ and B. Values are expressed as mean \pm S.E.M. of $n \geq 3$. ${ }^{*} P<0.05$ with respect to control.

\section{Regulation of fatty acid uptake by gAd and fAd in the presence of hyperglycemia or hyperinsulinemia}

We first examined the time-dependent ability of gAd to induce fluorescent fatty acid uptake in L6 cells, and, as shown in Fig. 4A, we found a maximal increase after $2 \mathrm{~h}$. This time of treatment was chosen to investigate the effect of gAd (Fig. 4B) and fAd (Fig. 4C) on fatty acid uptake under control, hyperinsulinemic and hyperglycemic conditions. gAd increased fatty acid uptake by $1 \cdot 6$-fold under normal conditions, an effect which was abolished by hyperinsulinemia and reduced by hyperglycemia (Fig. 4B). A small but significant increase in fatty acid uptake was observed in response to fAd only
A

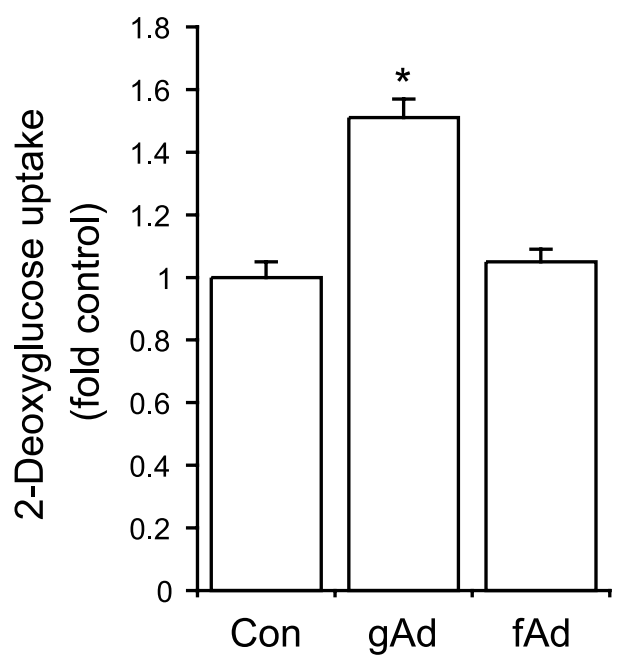

B

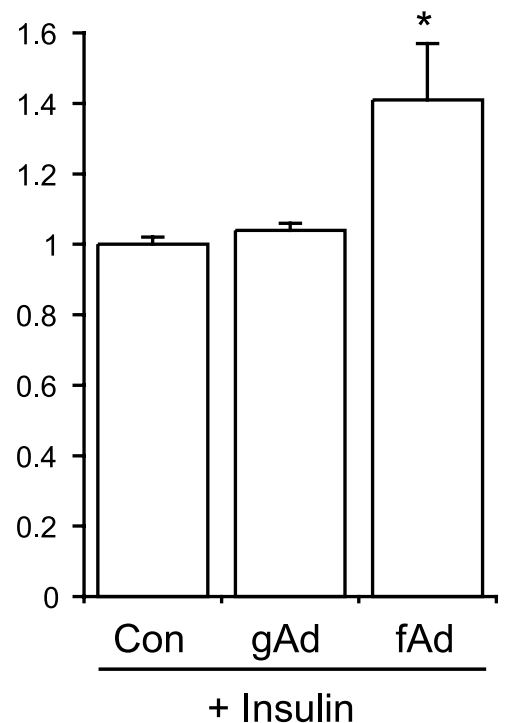

C

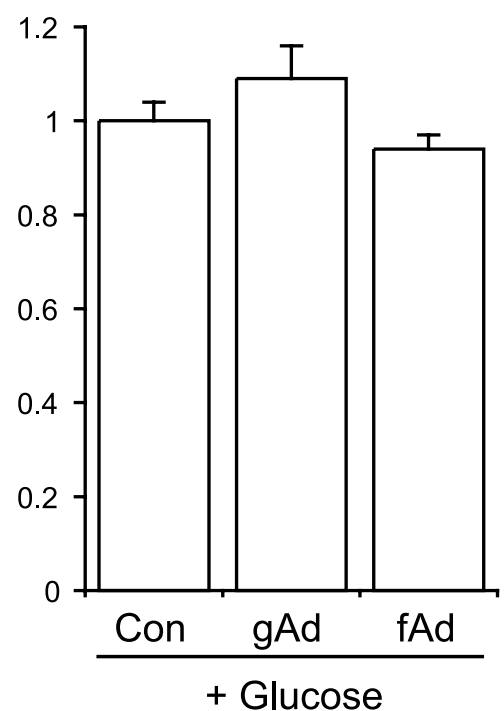

Figure 2 Effect of gAd and fAd on glucose uptake and regulation by hyperinsulinemia and hyperglycemia. Uptake of 2-deoxyglucose was measured in response to gAd $(1 \mu \mathrm{g} / \mathrm{ml}, 2 \mathrm{~h})$ or fAd $(5 \mu \mathrm{g} / \mathrm{ml}, 2 \mathrm{~h})$ in cells grown under normal growth conditions $(A)$ or in the presence of $(B)$ insulin $(100 \mathrm{nM}, 20 \mathrm{~h})$ or $(C)$ glucose $(25 \mathrm{mM}, 20 \mathrm{~h})$. Values are expressed as mean \pm S.E.M. of $n \geq 3$ where each condition was assayed in triplicate. ${ }^{*} P<0.05$ with respect to control. 


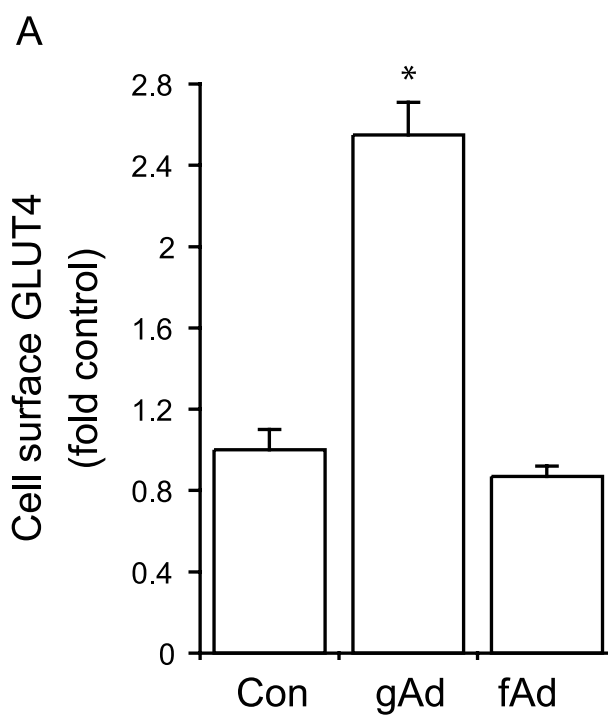

B

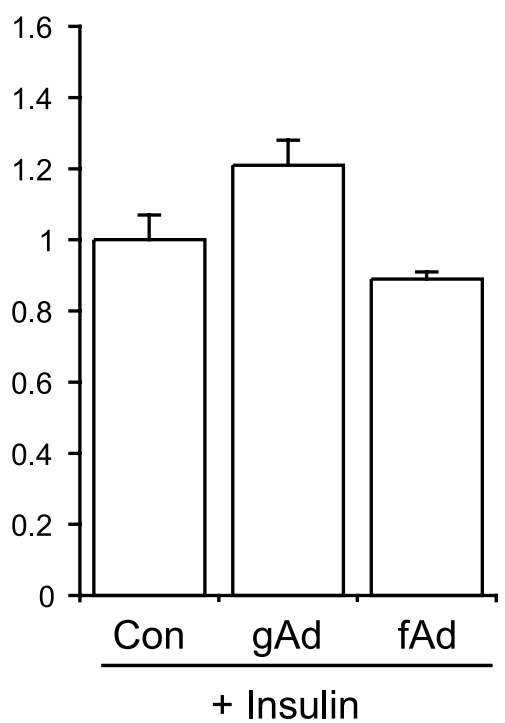

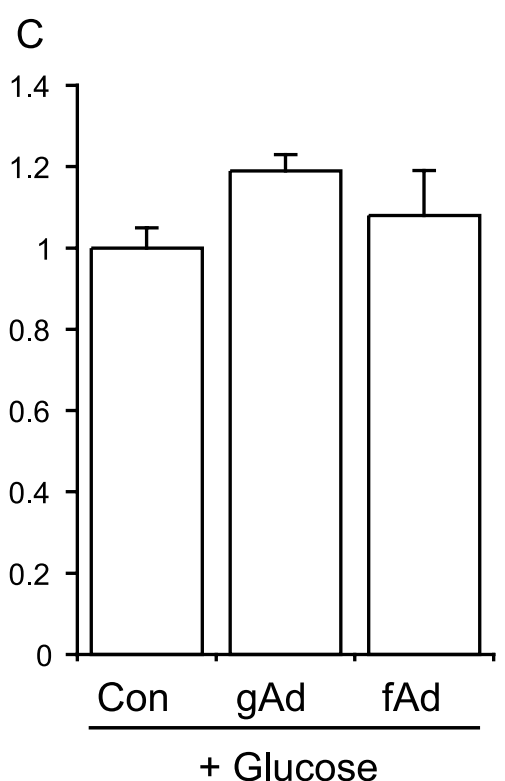

Figure 3 Effect of gAd and fAd on GLUT4 translocation and regulation by hyperinsulinemia and hyperglycemia. The amount of GLUT4 detected at the cell surface was measured in L6-GLUT4 myc cells in response to $\mathrm{gAd}(1 \mu \mathrm{g} / \mathrm{ml}, 2 \mathrm{~h})$ or fAd $(5 \mu \mathrm{g} / \mathrm{ml}, 2 \mathrm{~h})$ in cells grown under normal growth conditions (A) or in the presence of $(B)$ insulin $(100 \mathrm{nM}, 20 \mathrm{~h})$ or $(\mathrm{C})$ glucose $(25 \mathrm{mM}, 20 \mathrm{~h})$. Values are expressed as mean \pm S.E.M. of $n \geq 3$ experiments where each condition was assayed in triplicate. ${ }^{*} P<0.05$ with respect to control.

under hyperinsulinemic conditions (Fig. 4G). As can be seen, both hyperinsulinemia and hyperglycemia elevate the basal level of fatty acid uptake.

\section{Regulation of fatty acid oxidation by gAd and fAd in the presence of hyperglycemia or hyperinsulinemia}

Both gAd and fAd were found to increase fatty acid oxidation significantly (Fig. 5A), and this was prevented by hyperglycemia (Fig. 5C). Hyperinsulinemia reduced basal fatty acid oxidation levels, and abolished the ability of gAd and enhanced the ability of fAd to increase oxidation (Fig. 5B).

\section{Regulation of AMPK and ACC phosphorylation by gAd and fAd in the presence of hyperglycemia or hyperinsulinemia}

Figure 6A demonstrates that gAd significantly increases AMPK phosphorylation in L6 cells (average 1.51-fold from $n \geq 3$ ) under normal growth conditions, but not in the presence of hyperinsulinemia (0.95-fold) or hyperglycemia $(1 \cdot 14$-fold). ACG phosphorylation is also stimulated by gAd (1.49-fold) (Fig. 6C), and this effect is attenuated by both hyperinsulinemia $(1 \cdot 17$-fold $)$ and hyperglycemia $(1 \cdot 13$-fold). We also examined the effect of hyperinsulinemia and hyperglycemia on expression of AMPK isoforms and found that hyperinsulinemia causes an increase in AMPK- $\alpha 2$ expression (Fig. 6B). ACG expression was reduced by hyperinsulinemia and unaltered by hyperglycemia (Fig. 6D). There was a small but not significant stimulation of AMPK phosphorylation in response to fAd under normal and hyperglycemic conditions and no apparent change in the presence of hyperinsulinemia (Fig. 7A). ACG phosphorylation was significantly increased by fAd, 1.65-fold under normal conditions and 1.23-fold under hyperinsulinemia (Fig. 7B). This effect of fAd was not apparent $(1 \cdot 1$-fold) under hyperglycemia (Fig. 7B).

\section{Discussion}

There is currently great interest in the role played by adiponectin in glucose homeostasis; however, correlative studies represent the bulk of literature available to date. In this study, we have established a system to examine regulation of glucose and lipid metabolism by both gAd and fAd in skeletal muscle under conditions commonly observed in obese and diabetic individuals, namely, prolonged hyperglycemia or hyperinsulinemia. The recent identification of adiponectin receptors (Yamauchi et al. 2003) was an important step in understanding regulation of adiponectin function. However, regulation of adiponectin function is complex, as different oligomeric forms of fAd and gAd mediate distinct effects (Tsao et al. 2002a, 2003, Waki et al. 2003). Although some debate exists, circulating fAd has been found in monomeric, trimeric, hexameric and higher-order 

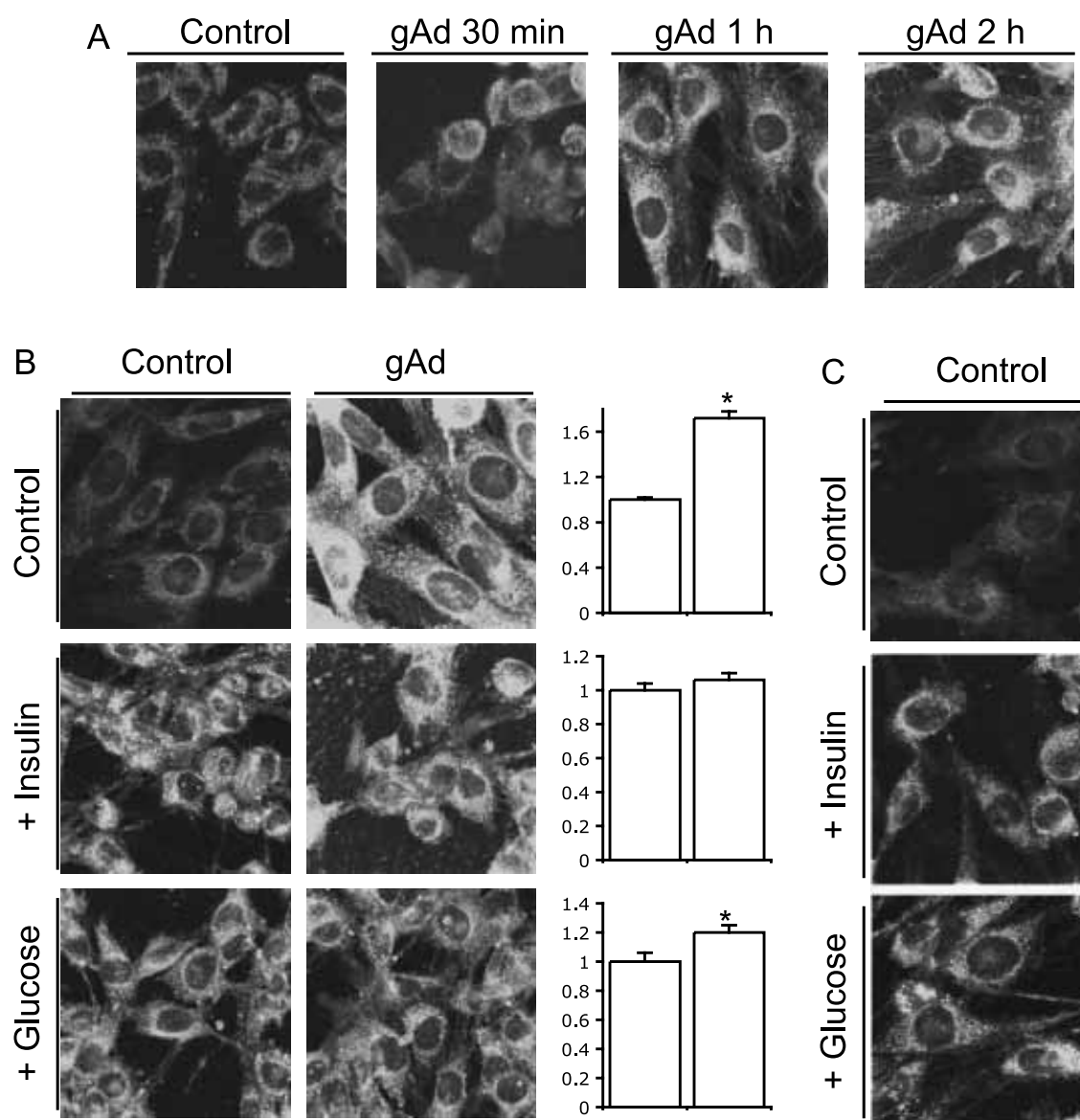
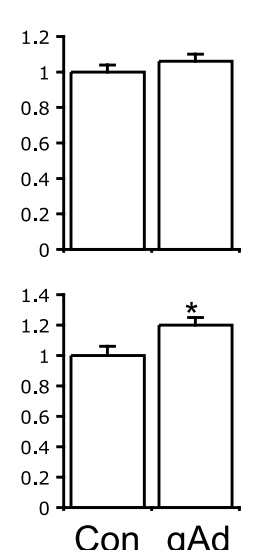

$\mathrm{C}$
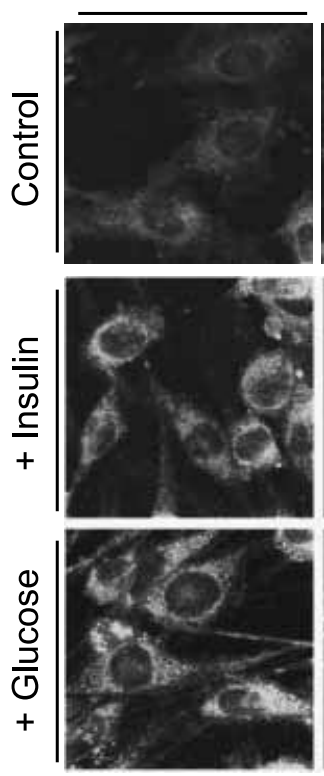

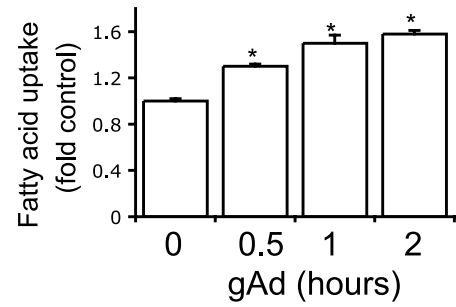

fAd
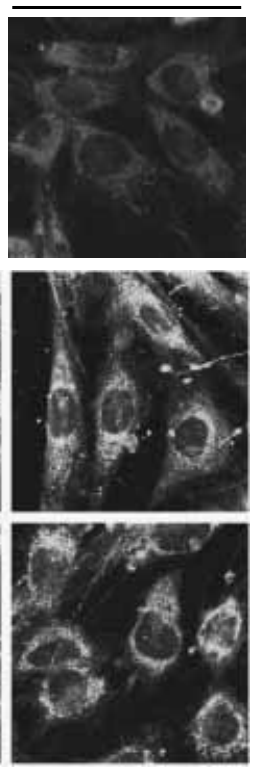
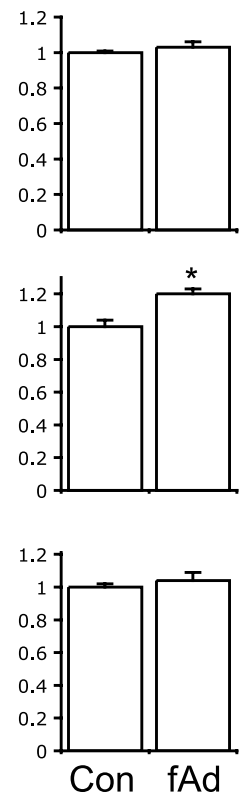

Figure 4 Effect of gAd and fAd on fatty acid uptake and regulation by hyperinsulinemia and hyperglycemia. The time course of gAd-stimulated fatty acid uptake was first established (A). Subsequently, uptake of BODIPY-palmitate was measured in response to (B) $\mathrm{gAd}(1 \mu \mathrm{g} / \mathrm{ml}, 2 \mathrm{~h})$ or (C) fAd $(5 \mu \mathrm{g} / \mathrm{ml}, 2 \mathrm{~h})$ in cells grown under normal growth conditions (control (Con)) or in the presence of insulin $(100 \mathrm{nM}, 20 \mathrm{~h})$ or glucose $(25 \mathrm{mM}, 20 \mathrm{~h})$. Representative images for each experiment are shown, and quantitative values, obtained by analyzing at least 20 individual cells from each independent experiment, are expressed as mean \pm S.E.M. ${ }^{*} P<0.05$ compared with control.

forms, whereas gAd exists as both a monomer and a trimer (Fruebis et al. 2001, Yamauchi et al. 2002, 2003, Pajvani et al. 2003, 2004, Shklyaev et al. 2003, Shoji et al. 2004, Wang et al. 2004). A fragment of adiponectin containing the globular domain can mediate metabolic effects, particularly in skeletal muscle (Fruebis et al. 2001, Yamauchi et al. 2003, Ceddia et al. 2005). Thus, cleavage of full-length adiponectin to liberate the globular domain by enzymes such as the recently characterized leukocyte elastase (Waki et al. 2005) may represent an important regulatory step in the function of adiponectin (Pajvani et al. 2003).

Using quantitative PCR, we show that L6 rat skeletal myoblasts express over six times more AdipoR1 than AdipoR2 mRNA. This is in keeping with their observed greater sensitivity to gAd (Ceddia et al. 2005), since it has been demonstrated that AdipoR1 contains both a high- and intermediate-affinity binding site for gAd, whereas AdipoR2 contains intermediate- and low-affinity binding sites for fAd (Yamauchi et al. 2003). Indeed, use of siRNA to remove AdipoR1 in C2C12 cells almost totally eliminated gAd binding but had little effect on fAd binding (Yamauchi et al. 2003). The converse was observed upon siRNA-induced reduction in AdipoR2 expression (Yamauchi et al. 2003). Previous work in mice also found that AdipoRl expression was highest in muscle (Civitarese et al. 2004), while another study demonstrated that human muscle contained 1.8-fold more AdipoR1 than AdipoR2 mRNA (Staiger et al. 2004). Here we show that EDL expresses a very similar ratio of AdipoR1 to AdipoR2 to that found in L6 cells, whereas soleus muscle appears to express little AdipoR2. Using epitope-tagged AdipoR, we and others have found that commercially available AdipoR antibodies 
A

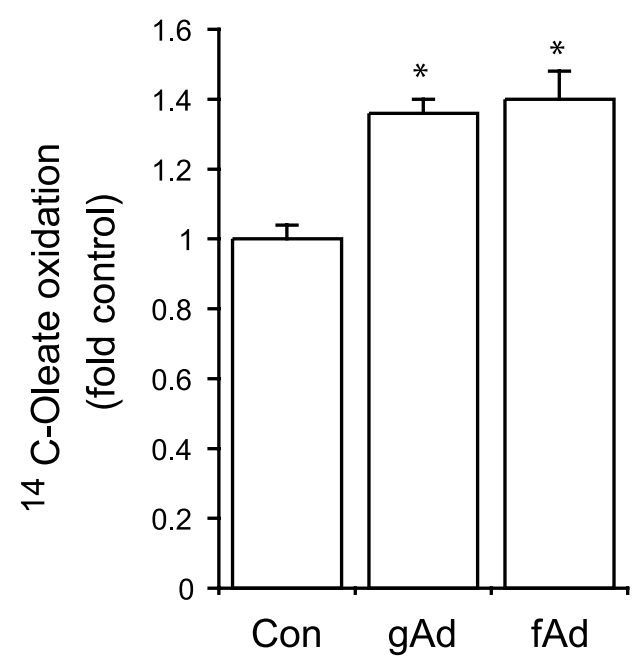

B

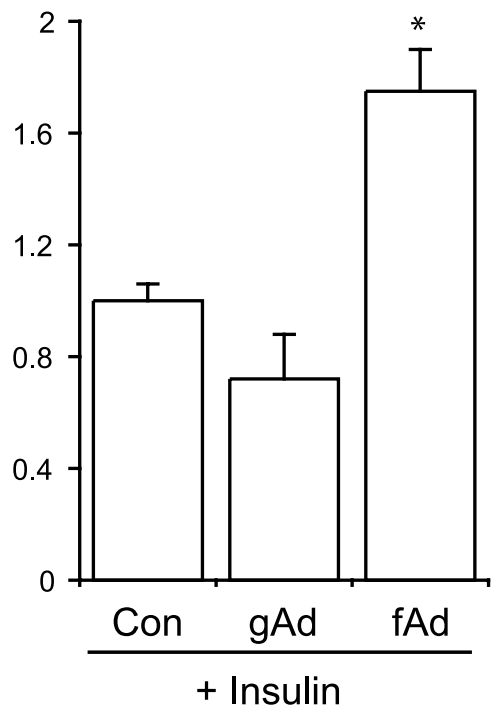

C

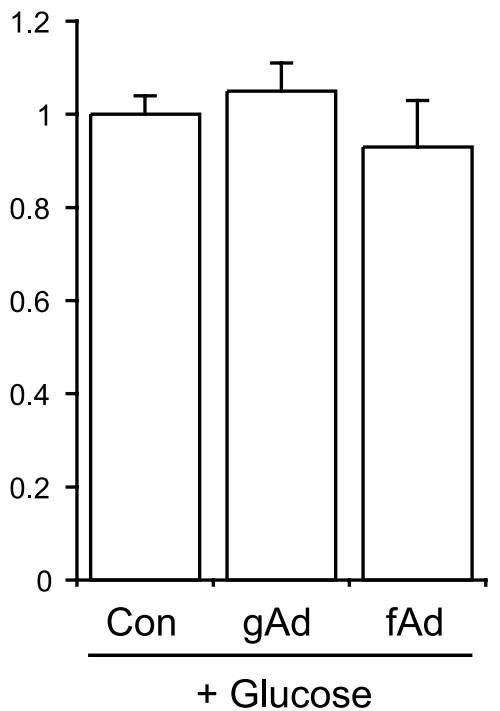

Figure 5 Effect of gAd and fAd on fatty acid oxidation and regulation by hyperinsulinemia and hyperglycemia. The production of ${ }_{14} \mathrm{CO}_{2}$ from $\left[1-{ }^{14} \mathrm{C}\right]$ oleate was examined in response to $\mathrm{gAd}(1 \mu \mathrm{g} / \mathrm{ml}, 2 \mathrm{~h})$ or $\mathrm{fAd}(5 \mu \mathrm{g} / \mathrm{ml}, 2 \mathrm{~h})$ in cells grown under normal growth conditions $(A)$ or in the presence of $(B)$ insulin $(100 \mathrm{nM}, 20 \mathrm{~h})$ or $(C)$ glucose $(25 \mathrm{mM}, 20 \mathrm{~h})$. Values are expressed as mean \pm S.E.M. of $n \geq 3$. ${ }^{*} P<0.05$ with respect to control.

are unreliable; therefore, we are in the process of making AdipoR antibodies. As we demonstrate here, regulation of AdipoR expression may be an important mechanism determining the function of adiponectin.

Increased AdipoR1 expression in skeletal muscle of STZ-diabetic mice was corrected by addition of insulin (Inukai et al. 2004, Tsuchida et al. 2004), and in C2C12 cells, insulin $(24 \mathrm{~h}$ ) reduced AdipoR1 expression (Inukai et al. 2004, Tsuchida et al. 2004). However, the reason why another study found no significant change in C2C12 myotube AdipoR1 mRNA expression in response to 28-h treatment with insulin is unclear (Staiger et al. 2004). Insulin did not alter AdipoR1 or AdipoR2 in adipocytes (Fasshauer et al. 2004), and expression of AdipoR1 and AdipoR2 in liver was not significantly changed in hypo- or hyperinsulinemic mouse models (Inukai et al. 2004). Here we showed that insulin decreased AdipoRl expression in rat skeletal muscle cells and, importantly, increased AdipoR2 expression. This raises the interesting possibility that hyperinsulinemia may make skeletal muscle cells resistant to gAd while inducing sensitivity to fAd. AdipoR 1 expression was decreased in hyperglycemic, obese $\mathrm{db} / \mathrm{db}$ mice (Inukai et al. 2004). AdipoR 1 and AdipoR2 were decreased in skeletal muscle of hyperglycemic ob/ob mice (Tsuchida et al. 2004) and increased in muscle and liver of fasted mice (Tsuchida et al. 2004). One study, which should be interpreted cautiously, has failed to detect any change in AdipoR mRNA expression in muscle of type 2 diabetic patients (Debard et al. 2004). We show here that glucose decreased AdipoR1 expression, without altering AdipoR2, suggesting that hyperglycemia may decrease the function of gAd.

We have demonstrated previously that gAd $(1 \mu \mathrm{g} / \mathrm{ml}$, $2 \mathrm{~h}$ ) increased glucose uptake in L6 cells by causing increased GLUT4 content at the cell surface (Ceddia et al. 2005). Concentrations of gAd of $0 \cdot 5-2.5 \mu \mathrm{g} / \mathrm{ml}$ (30 min) were found to increase glucose uptake significantly in C2C12 cells (Yamauchi et al. 2002) or rat EDL muscle (Tomas et al. 2002). It should be noted that in our own studies and the published literature, metabolic responses mediated by adiponectin are typically of a small but significant magnitude, and in vivo studies have validated the physiologic importance of the metabolic effects of adiponectin. Here we found a decrease in gAd-stimulated glucose uptake and cellsurface GLUT4 under hyperinsulinemic and hyperglycemic conditions. This is akin to previous studies to reduce AdipoR1 expression artificially with siRNA, whereupon decreased gAd- stimulated, but not fAdstimulated, glucose uptake and fatty acid oxidation were observed in C2C12 cells (Wang et al. 2004). We attribute the fact that fAd increased glucose uptake without altering GLUT4 translocation to glucose transport occurring through the elevated GLUT1 content found in cells grown in high insulin. We and others have shown previously that gAd increases fatty acid oxidation in skeletal muscle or cultured cells (Fruebis et al. 2001, Yamauchi et al. 2002, 2003, Geddia et al. 2005). We now 


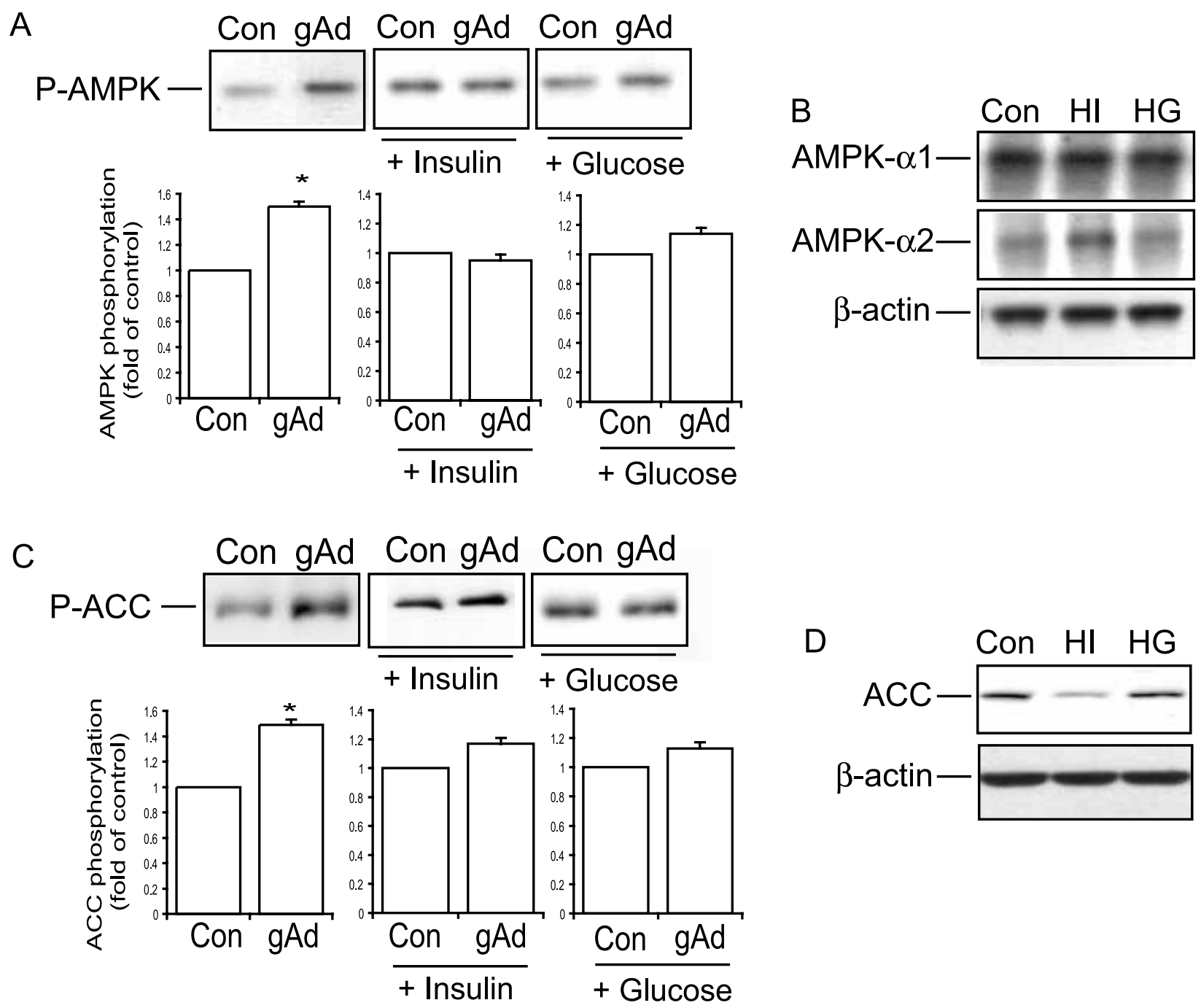

Figure 6 Effect of hyperinsulinemia and hyperglycemia on AMPK and ACC expression and their phosphorylation by gAd. The effects of $\mathrm{gAd}(1 \mathrm{\mu g} / \mathrm{ml}, 5 \mathrm{~min})$ on AMPK and ACC phosphorylation are shown in panels $\mathrm{A}$ and $\mathrm{C}$ respectively, using cells grown under normal conditions or in the presence of insulin $(100 \mathrm{nM}, 20 \mathrm{~h})$ or glucose $(25 \mathrm{mM}, 20 \mathrm{~h})$. The effect of insulin (HI: $100 \mathrm{nM}, 20 \mathrm{~h}$ ) or glucose (HG: $25 \mathrm{mM}, 20 \mathrm{~h}$ ) on expression of AMPK- $\alpha 1$ and AMPK- $\alpha 2$ isoforms is shown in panel B, and its effect on total ACC expression is shown in panel D, with $\beta$-actin used as a control in each case as shown. Representative immunoblots are shown for each quantitative analysis performed in experiments repeated at least three times. ${ }^{\star} P<0.05$ compared with control.

also have demonstrated that stimulation of both fatty acid uptake and oxidation by gAd is lost when cells are grown in hyperinsulinemic or hyperglycemic conditions. It should also be borne in mind that both cause an elevated level of basal fatty acid uptake that may contribute to the lower magnitude of response elicited by gAd under these conditions. Thus, our results suggest that alterations in the expression level of AdipoR 1 may represent an important potential node in determining the response of skeletal muscle cells to gAd.

The effects of fAd are thought to be mediated by AdipoR2 and under normal conditions occur primarily in liver. However, fAd $(2 \cdot 5 \mu \mathrm{g} / \mathrm{ml}, 30-60 \mathrm{~min})$ has been shown to stimulate glucose uptake and fatty acid oxidation in G2G12 cells (Yamauchi et al. 2002). Here we show that fAd does not alter cell-surface GLUT4 myc content, glucose or fatty acid uptake in L6 cells. Most interestingly, we show that the increased AdipoR2 expression induced by hyperinsulinemia correlates with induction of the ability of fAd to stimulate glucose and fatty acid uptake and to enhance further fatty acid oxidation. The physiologic significance of this novel observation must now be further investigated. Surprisingly, fAd increased glucose uptake, but not GLUT4 


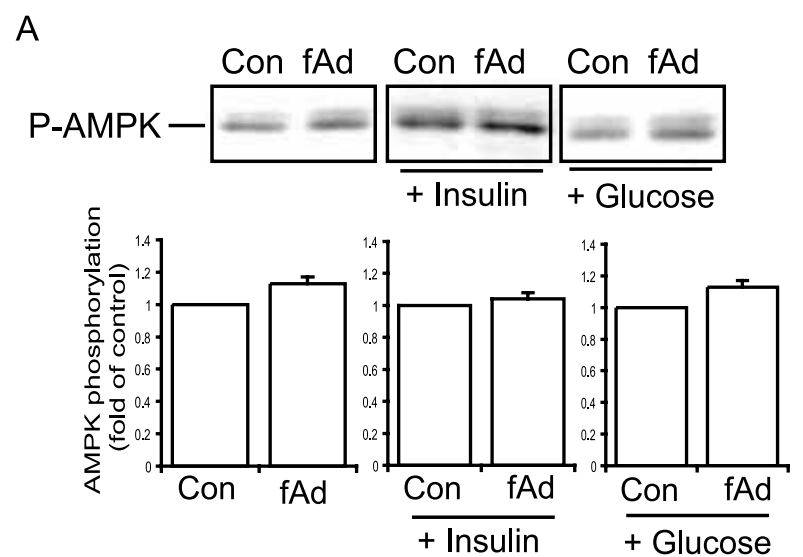

B

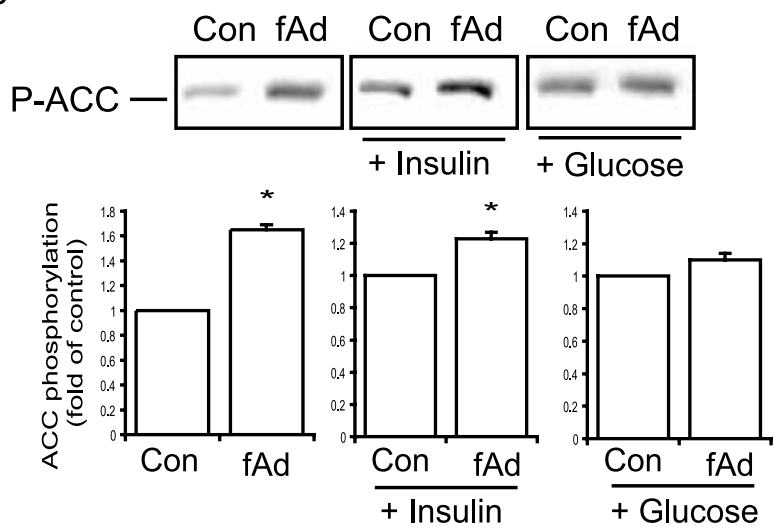

Figure 7 Effect of fAd on AMPK and ACC phosphorylation and regulation by hyperinsulinemia and hyperglycemia. The effects of fAd ( $5 \mu \mathrm{g} / \mathrm{ml}, 5 \mathrm{~min})$ on AMPK and ACC phosphorylation are shown in panels $A$ and $B$ respectively, using cells grown under normal conditions or in the presence of insulin (100 nM, $20 \mathrm{~h})$ or glucose $(25 \mathrm{mM}, 20 \mathrm{~h})$. Representative immunoblots are shown for each and quantitative analysis performed on experiments repeated at least three times. ${ }^{*} P<0.05$ compared with control.

myc translocation, under hyperinsulinemic conditions, and it may be that this occurs via the increased GLUT1 content found under these conditions (data not shown). Hyperglycemia-induced alterations in expression of a protein that plays a critical role in fatty acid oxidation may represent a nonspecific reason for the decrease in ACG phosphorylation and fatty acid oxidation mediated by fAd under these conditions.

Regulation of AMPK phosphorylation plays an important role in mediating many effects of adiponectin, including glucose uptake and fatty acid metabolism. Treatment of $\mathrm{C} 2 \mathrm{C} 12$ cells, rat extensor digitorum longus or soleus muscle with gAd and high concentrations of fAd resulted in increased AMPK activity (Tomas et al. 2002, Yamauchi et al. 2002). Furthermore, increased glucose uptake in response to both gAd and fAd in C2C12 cells was blocked by a dominant negative version of AMPK (Yamauchi et al. 2002). Here we confirm that gAd increased AMPK phosphorylation in L6 cells and show that this effect was prevented by both hyperinsulinemia and hyperglycemia. AMPK also phosphorylates and inhibits activity of ACC, and treatment of $\mathrm{C} 2 \mathrm{C} 12$ cells, rat extensor digitorum longus or soleus with gAd or fAd was shown to increase ACCa and ACC $\beta$ phosphorylation and decrease malonyl Co-A levels by 30\% (Tomas et al. 2002, Yamauchi et al. 2002). The increased ACG phosphorylation and fatty acid oxidation in response to both gAd and fAd in C2C12 cells was blocked by a dominant negative version of AMPK (Yamauchi et al. 2002). Importantly, our results show that gAd increased ACC phosphorylation, and this effect was attenuated when AdipoRl expression was reduced by hyperinsulinemia or hyperglycemia. ACG phosphorylation was significantly increased by fAd under normal and hyperinsulinemic conditions, but not in the presence of hyperglycemia, a result which is in keeping with the lack of oleate oxidation observed in response to fAd under the latter conditions. We observe that under some conditions AMPK and ACG phosphorylation in response to adiponectin do not correlate. This is not entirely surprising and has been documented previously in one of the first studies to examine the effect of adiponectin on skeletal muscle glucose uptake and metabolism (Tomas et al. 2002). The authors attributed this observation to temporal reasons or regulation of an alternative ACG kinase by adiponectin. Indeed, although AMPK activation is often regarded as being a prerequisite for ACG phosphorylation, several publications have demonstrated that several kinases can regulate ACG phosphorylation, albeit on additional residues including protein kinase A (Winder et al. 1997).

In this study, we have characterized the effect of insulin and glucose on AdipoR expression in L6 rat skeletal muscle cells. AdipoRl expression is decreased by both hyperinsulinemia and hyperglycemia, while AdipoR2 expression is induced by hyperinsulinemia. Importantly, we have correlated these changes with alterations in the functional effects of gAd and fAd on glucose and fatty acid uptake and metabolism. In summary, our results suggest that both hyperglycemia and hyperinsulinemia cause gAd resistance in rat skeletal muscle cells. However, hyperinsulinemia induces a switch toward induction of, or increase in, fAd sensitivity in these cells. Given the recent interest in the differential effects of various adiponectin forms - globular or various full-length oligomeric forms - we believe that our results may be of major pathophysiologic significance.

\section{Acknowledgements}

Funding was provided by Canadian Institutes of Health Research, Institute of Nutrition, Metabolism and 
Diabetes, via an operating grant to $\mathrm{G} S$ and by the Canadian Diabetes Association via a scholarship award to $\mathrm{G} \mathrm{S}$ in honor of the late Mary A Bodington. G S also acknowledges support of the Ontario Ministry of Economic Development and Trade via a Premier's Research Excellence Award. Funding from the Canada Foundation for Innovation and the Ontario Innovation Trust is also acknowledged. Z X holds a visiting scholar award from the China Scholarship Council. The authors declare that there is no conflict of interest that would prejudice the impartiality of this scientific work.

\section{References}

Altomonte J, Harbaran S, Richter A \& Dong H 2003 Fat depot-specific expression of adiponectin is impaired in Zucker fatty rats. Metabolism $\mathbf{5 2}$ 958-963.

Berg AH, Combs TP, Du X, Brownlee M \& Scherer PE 2001 The adipocyte-secreted protein Acrp30 enhances hepatic insulin action. Nature Medicine 7 947-953.

Berg AH, Combs TP \& Scherer PE 2002 ACRP30/adiponectin: an adipokine regulating glucose and lipid metabolism. Trends in Endocrinology and Metabolism 13 84-89.

Ceddia RB, Somwar R, Maida A, Fang X, Bikopoulos G \& Sweeney G 2005 Globular adiponectin increases GLUT4 translocation and glucose uptake but reduces glycogen synthesis in rat skeletal muscle cells. Diabetologia 48 132-139.

Civitarese AE, Jenkinson CP, Richardson D, Bajaj M, Cusi K, Kashyap S, Berria R, Belfort R, DeFronzo RA, Mandarino LJ \& Ravussin E 2004 Adiponectin receptors gene expression and insulin sensitivity in non-diabetic Mexican Americans with or without a family history of type 2 diabetes. Diabetologia 47 816-820.

Debard C, Laville M, Berbe V, Loizon E, Guillet C, Morio-Liondore B, Boirie Y \& Vidal H 2004 Expression of key genes of fatty acid oxidation, including adiponectin receptors, in skeletal muscle of type 2 diabetic patients. Diabetologia 47 917-925.

Diez JJ \& Iglesias P 2003 The role of the novel adipocyte-derived hormone adiponectin in human disease. European Fournal of Endocrinology 148 293-300.

Fasshauer M, Klein J, Kralisch S, Klier M, Lossner U, Bluher M \& Paschke R 2004 Growth hormone is a positive regulator of adiponectin receptor 2 in 3T3-L1 adipocytes. FEBS Letters 558 27-32.

Fisher FM, McTernan PG, Valsamakis G, Chetty R, Harte AL, Anwar AJ, Starcynski J, Crocker J, Barnett AH, McTernan CL \& Kumar S 2002 Differences in adiponectin protein expression: effect of fat depots and type 2 diabetic status. Hormone Metabolism and Research 34 650-654.

Fruebis J, Tsao TS, Javorschi S, Ebbets-Reed D, Erickson MR, Yen FT, Bihain BE \& Lodish HF 2001 Proteolytic cleavage product of $30-\mathrm{kDa}$ adipocyte complement-related protein increases fatty acid oxidation in muscle and causes weight loss in mice. PNAS 98 2005-2010.

Goldfine AB \& Kahn CR 2003 Adiponectin: linking the fat cell to insulin sensitivity. Lancet 362 1431-1432.

Halleux CM, Takahashi M, Delporte ML, Detry R, Funahashi T, Matsuzawa Y \& Brichard SM 2001 Secretion of adiponectin and regulation of apMl gene expression in human visceral adipose tissue. Biochemistry and Biophysics Research Communications $\mathbf{2 8 8}$ 1102-1107.

Haluzik M, Parizkova J \& Haluzik MM 2004 Adiponectin and its role in the obesity-induced insulin resistance and related complications. Physiology Research 53 123-129.
Hirsch D, Stahl A \& Lodish HF 1998 A family of fatty acid transporters conserved from mycobacterium to man. PNAS 95 8625-8629.

Inukai K, Nakashima Y, Watanabe M, Takata N, Sawa T, Kurihara S, Awata T \& Katayama S 2004 Regulation of adiponectin receptor gene expression in diabetic mice. American Fournal of Physiology. Endocrinology and Metabolism 288 E876-882.

Kershaw EE \& Flier JS 2004 Adipose tissue as an endocrine organ. Journal of Clinical Endocrinology and Metabolism 89 2548-2556.

Milan G, Granzotto M, Scarda A, Calcagno A, Pagano C, Federspil G \& Vettor R 2002 Resistin and adiponectin expression in visceral fat of obese rats: effect of weight loss. Obesity Research $\mathbf{1 0}$ 1095-1103.

Pajvani UB, Du X, Combs TP, Berg AH, Rajala MW, Schulthess T, Engel J, Brownlee M \& Scherer PE 2003 Structure-function studies of the adipocyte-secreted hormone Acrp30/adiponectin. Implications for metabolic regulation and bioactivity. Fournal of Biological Chemistry 278 9073-9085.

Pajvani UB, Hawkins M, Combs TP, Rajala MW, Doebber T, Berger JP, Wagner JA, Wu M, Knopps A, Xiang AH, Utzschneider KM, Kahn SE, Olefsky JM, Buchanan TA \& Scherer PE 2004 Complex distribution, not absolute amount of adiponectin, correlates with thiazolidinedione-mediated improvement in insulin sensitivity. Fournal of Biological Chemistry $\mathbf{2 7 9}$ $12152-12162$.

Scherer PE, Williams S, Fogliano M, Baldini G \& Lodish HF 1995 A novel serum protein similar to $\mathrm{Clq}$, produced exclusively in adipocytes. Fournal of Biological Chemistry 270 26746-26749.

Shklyaev S, Aslanidi G, Tennant M, Prima V, Kohlbrenner E, Kroutov V, Campbell-Thompson M, Crawford J, Shek EW, Scarpace PJ \& Zolotukhin S 2003 Sustained peripheral expression of transgene adiponectin offsets the development of diet-induced obesity in rats. PNAS $\mathbf{1 0 0} 14217-14222$.

Shoji T, Kimoto E, Shinohara K, Hatsuda S \& Nishizawa Y 2004 Molecular forms of adiponectin in uraemic plasma. Nephrology, Dialysis, Transplantation 19 1937-1938.

Stahl A, Evans JG, Pattel S, Hirsch D \& Lodish HF 2002 Insulin causes fatty acid transport protein translocation and enhanced fatty acid uptake in adipocytes. Developmental Cell 2 477-488.

Staiger H, Kaltenbach S, Staiger K, Stefan N, Fritsche A, Guirguis A, Peterfi C, Weisser M, Machicao F, Stumvoll M \& Haring HU 2004 Expression of adiponectin receptor mRNA in human skeletal muscle cells is related to in vivo parameters of glucose and lipid metabolism. Diabetes 53 2195-2201.

Statnick MA, Beavers LS, Conner LJ, Corominola H, Johnson D, Hammond CD, Rafaeloff-Phail R, Seng T, Suter TM, Sluka JP, Ravussin E, Gadski RA \& Caro JF 2000 Decreased expression of apM1 in omental and subcutaneous adipose tissue of humans with type 2 diabetes. International Foumal of Experimental Diabetes Research $\mathbf{1}$ 81-88.

Sweeney G, Keen J, Somwar R, Konrad D, Garg R \& Klip A 2001 High leptin levels acutely inhibit insulin-stimulated glucose uptake without affecting GLUT4 translocation in L6 rat skeletal muscle cells. Endocrinology 142 4806-4812.

Tajmir P, Kwan JJ, Kessas M, Mozammel S \& Sweeney G 2003 Acute and chronic leptin treatment mediates contrasting effects on signaling, glucose uptake, and GLUT4 translocation in L6-GLUT4 myc myotubes. Fournal of Cell Physiology 197 122-130.

Tomas E, Tsao TS, Saha AK, Murrey HE, Zhang CC, Itani SI, Lodish HF \& Ruderman NB 2002 Enhanced muscle fat oxidation and glucose transport by ACRP30 globular domain: acetyl-CoA carboxylase inhibition and AMP-activated protein kinase activation. PNAS 99 16309-16313.

Tsao TS, Lodish HF \& Fruebis J 2002a ACRP30, a new hormone controlling fat and glucose metabolism. European fournal of Pharmacology 440 213-221.

Tsao TS, Murrey HE, Hug C, Lee DH \& Lodish HF $2002 b$ Oligomerization state-dependent activation of NF-kappa B 
signaling pathway by adipocyte complement-related protein of $30 \mathrm{kDa}$ (Acrp30). Fournal of Biological Chemistry 277 29359-29362.

Tsao TS, Tomas E, Murrey HE, Hug C, Lee DH, Ruderman NB, Heuser JE \& Lodish HF 2003 Role of disulfide bonds in Acrp30/adiponectin structure and signaling specificity. Different oligomers activate different signal transduction pathways. Fournal of Biological Chemistry 278 50810-50817.

Tsuchida A, Yamauchi T, Ito Y, Hada Y, Maki T, Takekawa S, Kamon J, Kobayashi M, Suzuki R, Hara K, Kubota N, Terauchi Y, Froguel P, Nakae J, Kasuga M, Accili D, Tobe K, Ueki K, Nagai R \& Kadowaki T 2004 Insulin/Foxol pathway regulates expression levels of adiponectin receptors and adiponectin sensitivity. Fournal of Biological Chemistry 279 30817-30822.

Vigouroux C, Maachi M, Nguyen TH, Coussieu C, Gharakhanian S, Funahashi T, Matsuzawa Y, Shimomura I, Rozenbaum W, Capeau J \& Bastard JP 2003 Serum adipocytokines are related to lipodystrophy and metabolic disorders in HIV-infected men under antiretroviral therapy. AIDS 17 1503-1511.

Waki H, Yamauchi T, Kamon J, Ito Y, Uchida S, Kita S, Hara K, Hada Y, Vasseur F, Froguel P, Kimura S, Nagai R \& Kadowaki T 2003 Impaired multimerization of human adiponectin mutants associated with diabetes. Molecular structure and multimer formation of adiponectin. Fournal of Biological Chemistry 278 40352-40363.

Waki H, Yamauchi T, Kamon J, Kita S, Ito Y, Hada Y, Uchida S, Tsuchida A, Takekawa S \& Kadowaki T 2005 Generation of globular fragment of adiponectin by leukocyte elastase secreted by monocytic cell line THP-1. Endocrinology 146 790-796.

Wang Y, Xu A, Knight C, Xu LY \& Cooper GJ 2002

Hydroxylation and glycosylation of the four conserved lysine residues in the collagenous domain of adiponectin. Potential role in the modulation of its insulin-sensitizing activity. Fournal of Biological Chemistry 277 19521-19529.

Wang Y, Lu G, Wong WP, Vliegenthart JF, Gerwig GJ, Lam KS, Cooper GJ \& Xu A 2004 Proteomic and functional characterization of endogenous adiponectin purified from fetal bovine serum. Proteomics 4 3933-3942.

Winder WW, Wilson HA, Hardie DG, Rasmussen BB, Hutber CA, Call GB, Clayton RD, Conley LM, Yoon S \& Zhou B 1997
Phosphorylation of rat muscle acetyl-CoA carboxylase by AMP-activated protein kinase and protein kinase A. Journal of Applied Physiology 82 219-225.

Xu A, Wang Y, Keshaw H, Xu LY, Lam KS \& Cooper GJ 2003 The fat-derived hormone adiponectin alleviates alcoholic and nonalcoholic fatty liver diseases in mice. Fournal of Clinical Investigation 112 91-100.

Yamauchi T, Kamon J, Waki H, Terauchi Y, Kubota N, Hara K, Mori Y, Ide T, Murakami K, Tsuboyama-Kasaoka N, Ezaki O, Akanuma Y, Gavrilova O, Vinson C, Reitman ML, Kagechika H, Shudo K, Yoda M, Nakano Y, Tobe K, Nagai R, Kimura S, Tomita M, Froguel P \& Kadowaki T 2001 The fat-derived hormone adiponectin reverses insulin resistance associated with both lipoatrophy and obesity. Nature Medicine 7 941-946.

Yamauchi T, Kamon J, Minokoshi Y, Ito Y, Waki H, Uchida S, Yamashita S, Noda M, Kita S, Ueki K, Eto K, Akanuma Y, Froguel P, Foufelle F, Ferre P, Carling D, Kimura S, Nagai R, Kahn BB \& Kadowaki T 2002 Adiponectin stimulates glucose utilization and fatty-acid oxidation by activating AMP-activated protein kinase. Nature Medicine 8 1288-1295.

Yamauchi T, Kamon J, Ito Y, Tsuchida A, Yokomizo T, Kita S, Sugiyama T, Miyagishi M, Hara K, Tsunoda M, Murakami K, Ohteki T, Uchida S, Takekawa S, Waki H, Tsuno NH, Shibata Y, Terauchi Y, Froguel P, Tobe K, Koyasu S, Taira K, Kitamura T, Shimizu T, Nagai R \& Kadowaki T 2003 Cloning of adiponectin receptors that mediate antidiabetic metabolic effects. Nature $2003 \mathbf{4 2 3} 762-769$.

Yang WS, Lee WJ, Funahashi T, Tanaka S, Matsuzawa Y, Chao CL, Chen CL, Tai TY \& Chuang LM 2001 Weight reduction increases plasma levels of an adipose-derived anti-inflammatory protein, adiponectin. Fournal of Clinical Endocrinology and Metabolism 86 3815-3819.

Received in final form 9 September 2005

Accepted 9 September 2005

Made available online as an Accepted Preprint 5 October 2005 